\title{
Time and memory: historic accounts of Aboriginal burials in south-eastern Australia
}

\author{
Judith Littleton
}

In 1971, Betty Meehan undertook an important survey of historical accounts of burial practices among Aboriginal Australians highlighting regional variation across Australia. ${ }^{1}$ Since the late 1980s archaeologists have studied the archaeological record of burials to discover what it might indicate about pre-contact A boriginal social structure and relationships to land and resources. Historic accounts provide an ancillary source in this endeavour indicating variability in burial practices or providing explanations for particular archaeological findings. ${ }^{2}$ Yet, historic accounts are temporally limited (hours, days, weeks, years) in a way that the archaeological record cannot be and hence reveal the messiness and complexity of human actions around burials, which leave no, or a very limited, archaeological signature.

This paper analyses the significance of the temporal scal es encompassed by historical records and ultimately reflects on what this might mean for the archaeological record. Both the archaeological and historical records are temporal palimpsests. In his archaeological analysis of a single burial, the Hochdorf princely grave, Olivier demonstrated that different components of a burial have different temporal depth: from the time of production of particular artefacts to the instant of death, to the length of the burial act and the longevity of the monument. ${ }^{3}$ Historic accounts, however, encompass distinctions beyond these. The process of burial, as well as its after-effects, was observed. In other words historical records can be informative on the duration of human action and memory related to a burial. They tell us about the memory relating to the monument and other visible traces, distinguished by Bradley as inscribed memories and as incorporated memory associated with the fleeting acts of individuals. ${ }^{4}$ They also point to the difference between accounts of specific events or observations and the generalised statements of A boriginal burial practices made by early Europeans.

The current analysis focuses on the historic accounts of death, burial, and mourning practices for the central Murray area (from Echuca to the Northwest Bend) over the time period from first European accounts to the early 1900s. Death is a major life-crisis

\footnotetext{
1. Meehan 1971.

2. Pardoe 1988, 1995; Russell 1990; Littleton 2002.

3. Olivier 1999.

4. Bradley 2000: 157-158.
} 
for any community, especially for an intimate and kin-linked community such as Aboriginal society. In this situation the burial itself is one moment within a process that has a number of different elements: the death, the disposal, the memorialisation, mourning and actions flowing from the visible monument and its eventual decay. This paper will follow that temporal structure.

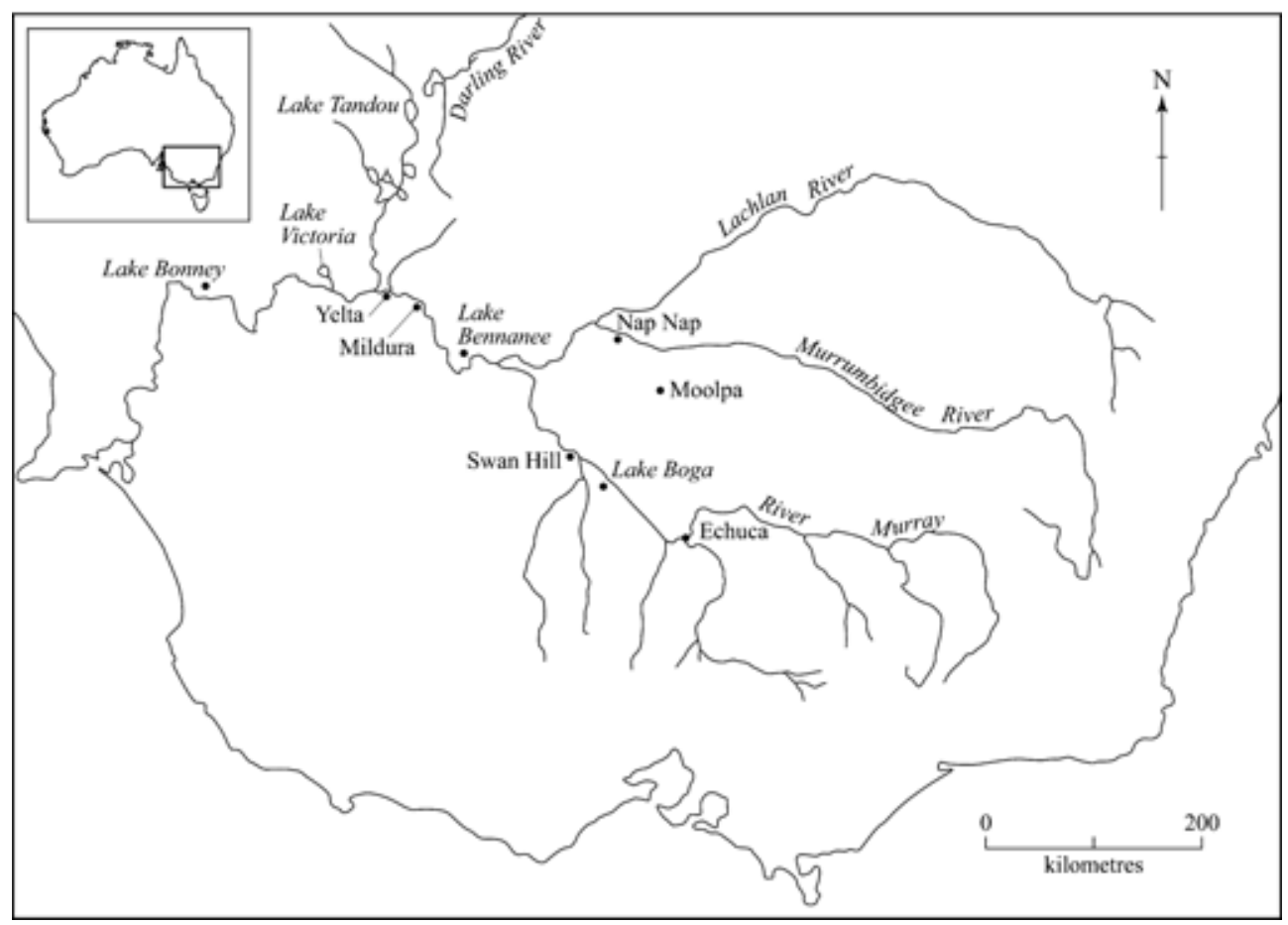

Fig 1. The central Murray region.

\section{D ata sources and shortcomings}

The records come from the central M urray area (Fig 1 ) and include, apart from those archival sources used by Meehan, some local diaries (eg Hobler) and newspaper accounts (particularly The Pastoral Times). This is a preliminary survey and there are no doubt sources that have been missed - but amongst the sources there are repetitive themes. It al so needs to be remembered that sources sometimes refer to each other. For example, Browne refers to Mitchell's observations and they no doubt inform his own interpretations. ${ }^{5}$ In addition some practices are referred to with no clear indication of either the source of the observation or its place.

A ccounts of burials are a product of a particular historical moment, not necessarily a reflection of a permanent pattern although they were often described as such by European writers. Infectious disease from the Europeans arrived in the area before any direct contact was made between the colonists and Aboriginal people. ${ }^{6}$ Aboriginal

5. Browne 1966[1844-5]: 31.

6. Dowling 1997. 
accounts, collected by Europeans after settlement, describe disease (probably smallpox) as coming with a great wind from various directions (from the south, up the river, from the east).

Europeans arriving in the district describe pock-marking among individuals. For example, Pulteney Mein at Moolpa wrote:

The Blacks must have suffered from smallpox before the advent of the Europeans in the Murray district for there was a man at Moolpa in 1858, from 35 to 40 years of age, who was perfectly blind, and he was deeply pitted with the small pox marks - King Phillip told me 'Jimmy' became blind when he was 10 or 11 years old - He also told me that so many Blacks died [about the time Jimmy became blind] on the Murray that they let the bodies remain in the camps, 'could not bury them, too many'. ${ }^{7}$

This means that all historic accounts need to be interpreted in the awareness that the Aboriginal people alive at the time were the survivors of serious epidemics and the other impacts of the colonial process and this no doubt affected the transmission of cultural concepts and knowledge. At the very least, the distribution of people in the landscape does not necessarily represent the pre-contact pattern. A part from this temporal gap, there is also the strong desire of many observers of the time to describe patterns or categorise activities. Hence accounts of single burials are often assumed by their authors to represent all burials within a particular area or even further afield.

\section{Burials vary over space}

Meehan's initial work on the historic sources was explicitly directed towards identifying regional distributions and variations in burial practices. Even within the Murray Basin such differences were noted very early on. ${ }^{8}$ They appear in two types of accounts: those of people moving through the country either on trips of exploration (as with Mitchell) or overlanding expeditions; and the more general accounts of later ethnographers who were collecting information from numerous sources. ${ }^{9}$ This means that there is relatively extensive information on differences in the visible monuments, but much less on differences in the more intimate processes of burial (more frequently noted by people who settled in the area and wrote accounts at the time or attempted to write memoirs) except where such events involved long term or multistage ceremonies such as exposure on platforms or secondary deposition.

In the Murray Basin there is a distinction between the practices performed on the Lower Murray (where secondary burials did occur) and those upstream (Fig 1). This paper deals only with the upstream accounts where recorded burials and monuments are dominated by primary interments. In this upper area there are also variations in visible monuments: for example, Mitchell distinguishes between the monuments of the Bogan/ Macquarie Marshes, the Darling, the Lachlan and the Murray-M urrumbidgee. ${ }^{10}$ These divisions do not define mutually exclusive groups of practices and in the follow-

7. Mein 1897, 25 October.

8. Sturt 1833: 52; Mitchell 1838; Moorhouse 1844: 357.

9. For example, Smyth 1876.

10. Mitchell 1838II: 113. 
ing analysis the different aspects of burial are dealt with, rather than defining regions and then describing them one by one.

\section{D eaths are caused by others}

One common feature of all accounts of burial is that death was caused by others. ${ }^{11}$ There are some caveats to this: MacKenzie suggests that the search for someone to blame for a death only occurred if the death was of a man and particularly of a young man. ${ }^{12}$ Beveridge isolates deaths caused by direct violence as those where there was no requirement to search for the guilty. ${ }^{13}$

The guilty were found and identified through various means, for example, the discovery of animal tracks near the grave after burial. ${ }^{14}$ These were interpreted as identifying the person to blame for the death and gave a focus for revenge. Hobler, at Nap Nap on the Murrumbidgee, describes how, when it was thought Dicky had died, the men rallied and started to walk off to Cunnargo in order to revenge his death. ${ }^{15}$ Dicky fortunately turned up soon after.

It is not intended here to address the whole issue of inquests, attribution of blame and so on, matters that fascinated Europeans. ${ }^{16}$ The point is that deaths were, by their nature, social occurrences involving not just the local group but potentially groups separated by long distances. Although their involvement was rarely in the actual processes of burial and mourning, the cycles of death and revenge linked people in a series of obligations. A single death could ramify outwards, with the actual burial having a minor role. This is the reverse situation to archaeology which, of course, begins with the burial.

\section{Who is buried?}

The few accounts of burial are nearly al ways of adult males and many authors distinguish between adult males and others in respect to burial practices. ${ }^{17}$ There seem to be two specific factors underlying this bias. First is the identity of those recording - most were males. There are three accounts by women in the current survey (all as young children) as opposed to more than 30 accounts by males. One of the few explicit descriptions of the burial of a child was made by a woman. ${ }^{18}$ The second factor is a gender bias in burial practices. Mitchell, for instance, specifies that men and boys had mounds constructed for their remains implying women and female children did not. ${ }^{19}$ Beveridge similarly points out that burial huts were restricted to a person of weight or consideration and later distinguishes these burials from the rudimentary disposal of women and 'Wittals of long standing'. ${ }^{20}$ A mong Meehan's data there are 16 references

\footnotetext{
11. Jamieson in Bride 1969: 381; Phillips 1893: 76.

12. Mackenzie 1870: 137.

13. Beveridge 1883: 52.

14. Kirby 1896.

15. Hobler 1992[1882]: 22 A pril 1848.

16. Jamieson in Bride 1969: 383; M oorhouse 1844: 357.

17. Hobler 1992[1882]: 7 March 1847; Jamieson in Bride 1969: 382.

18. Musgrave 1930.

19. Mitchell 1838II: 87.

20. Beveridge 1883: 12 .
} 
to men, four to women, four to children, and seven with gender unmentioned. Nevertheless, in most circumstances, everyone was buried.

Accounts are that women were buried with less ceremony and less communal mourning. ${ }^{21}$ Beveridge in his 1883 account is rather more sensational, stating that in relation to old women or 'wittals':

a shallow hole is merely scraped in the most convenient spot, having due regard to proximity and softness of soil, where in the body is careless thrown without the slightest preparation or ceremony, covered up and forgotten, unless, indeed, the shallow grave chances to be scraped. ${ }^{22}$

Infants (Beveridge specifies up to two years) and young children were the one group for whom there was routine secondary disposal. There are several accounts from a broad area (beyond the Murray River) of the infant being swaddled, bound and carried for several months before being finally disposed of through burial (in the central and Upper Murray) or being burnt (and possibly still carried for a short time) or being placed in a tree. Beveridge suggests that such practices were restricted to the first born son though Beveridge likes to put rules forward. ${ }^{23}$ Smyth specifies children who were 'well loved', 24 although there is plenty of evidence that most children fell into this category. It is not clear whether there was an upper age limit on the practice but the difference between children and others is marked in terms of burial practices. The accounts refer to a fairly wide area of $\mathrm{N}$ ew South Wales and Victoria. ${ }^{25}$

In total, therefore, the classes and statuses that are mentioned for different burial are: important men, all adult men, women (slight grading for age) and men of very low status and infants. The most elaborate constructions and processes were restricted to men and to infants, although infant deaths do not appear to be such public occasions. The visibility of public occasions, as opposed to more private events, may explain the apparent bias in favour of males, but it al so means that most written accounts of burials are also biased towards these members of society, particularly in circumstances of limited contact between observers and the observed.

\section{The disposal event}

In the historical accounts, apart from children, burial occurred soon after death and was primary. The accounts of Clow and Hobler are both of quite speedy burials. ${ }^{26} \mathrm{Clow}$ (Mildura region) having heard mourning cries, describes the subsequent burial:

On reaching the group, which consisted of two of Geordie's wives and two or three men who were winding a blanket round a corpse which was lying about half way between their camp and my hut, the men preserved a determined silence to all my inquiries, and it was from the women that I ascertained the corpse was their late husband, and that he had been murdered by some of the men who had been encamped with them. ${ }^{27}$

21. Curr 1965[1883]: 127; Jamieson in Bride 1969: 382.

22. Beveridge 1883: 12.

23. Beveridge 1883: 12.

24. Smyth 1876: 98.

25. Witter et al 1993; Littleton 2002: 112.

26. Clow in Bride 1969: 358; H obler 1992[1882]: 7 March 1847. 
With the exception of children (mentioned above) there are no accounts of long waits, or of moving the body long distances, after burial. Rather, burial is described as taking place quickly and locally. ${ }^{28}$ The one contrary general account is that of Smyth ${ }^{29}$ and it is difficult in this case to discern who he means by 'north and northeast tribes': north and north-east Victoria or north and north-east Australia? Certainly his account in relation to adults does not match other contemporary accounts from the Murray Valley area.

There are only two specific exceptions to the notion of a speedy burial close to the place of death. One is an account by a stockman to the Kerridge family on Lake Victoria. ${ }^{30} \mathrm{He}$ claimed that, after the Rufus River massacre, the bodies were transported by canoe across the lake to be buried. This does not, however, match accounts by O'HalIoran, Sturt and others of seeing the mound on the bank of the Rufus River where the massacred bodies were buried. 31

The other account is from The Pastoral Times (Deniliquin). On 20 January 1860, it was noted:

Died - Some time since the King of Werai died at Deniliquin ... He was buried at Deniliquin, but his remains were considered too sacred to be allowed a final resting-place in this stirring neighbourhood. The remnant of his tribe came up from Werai [about 100 miles by water] for their king, took him home in their canoes, and re-buried him. ${ }^{32}$

Two features make this particular burial unusual: one, the man who died was (in Beveridge's terms) a man of note, and, two, his initial burial was well away from his home country.

Immediate burial was the desirable state; absentees had to accommodate this. Bulmer mentions that if friends were not present at death then they hit themselves on the head, which seems a way of compensating for their absence from the burial cere mony. ${ }^{33}$ In this particular region burials were not delayed by waiting either for particular people or in order to transport the corpse to particular places. Rather, they were immediate acts so that only those camping with the dead were involved in the precise decisions regarding burial. This means there are potentially differences in the sorts of memories that could accrue to burials.

\section{Place of burial}

Most frequently the place of burial is described as nearby, either in soft ground or in a neighbouring sandhill. In general there is scant reference to specific places or specific choices of places in the historic accounts and much more emphasis on convenience. The references in terms of places are in respect to easy or soft digging. ${ }^{34}$ The exception to

27. Clow in Bride 1969: 358.

28. Bulmer 1888: 16; Jamieson in Bride 1969: 382; Hobler 1992[1882]: 7 March 1847.

29. Smyth 1876: 108.

30. Hope 1998: 101.

31. O'Halloran 1903-4: 86; Sturt 1849: 93.

32. Mulham 1994: 1.

33. Campbell 1994: 30.

34. Anon 1901: 17June; Curr 1965[1883]: 127; Phillips 1893: 74. 
this is Smyth in reference to the Bogan River. ${ }^{35}$ Both Stone and Beveridge argue that burials in oven mounds were rare. ${ }^{36}$ Despite his own excavation of burials from an oven mound, Stone, a local butcher and amateur archaeologist, writes:

in rare instances an aboriginal skeleton has been found when these ovens have been ploughed over or removed but I do not think that the practice of burying a deceased member of the tribe in an oven was often resorted to. ${ }^{37}$

Beveridge, on the other hand acknowledges that Aboriginal skeletons were frequently found in cooking mounds, but explains this by reference to isolated deaths, instances where there was no soft ground available and restricted to 'old worn out women or invalids of long standing, and who had become troublesome and tiresome to their unwilling attendants'. ${ }^{38} \mathrm{H}$ is excavation of burials from a mound is attributed to smallpox deaths which is a common explanation attributed to groups of multiple burials. This form of special pleading when observations do not match oral accounts is common, reflecting the difference between standardised accounts and actual events. ${ }^{39}$ The difference between general and particular descriptions points to a strong tendency for some writers to imply a greater level of formalism and regularity in burial than actually existed.

\section{The actual burial}

In contrast to the lack of specificity about burial locations, European accounts of the actual grave preparation and placement of the body are very detailed and give an impression of unvarying rules. Matthew, for example, writes: 'I am informed [by Mr Humphrey Davy] that on the Lachlan and Murrumbidgee the dead body was deposited with the head towards the south. ${ }^{40}$ Beveridge is equally clear:

The graves are usually about four feet deep, and in every instance bearing east and west. In the bottom of the grave a sheet of bark is placed or should bark be difficult to procure, it is thickly strewn with grass instead; the body is then let down with the feet towards the east. 41

Curr, Stone and Bulmer all make comments specific to particular tribes. Curr writes:

The Bangerang mode of burial had nothing remarkable about it. The dead were rolled up in their opossum-rugs, the knees being drawn up to the neck with strings, when the corpse was interred in a sitting posture, or on its side. 42

On the other hand, Bulmer suggests that at Yelta the orientation of the body was significantly related to totem:

On the Murray, the position the body was placed in the grave as determined by the person's totem; grokitch was buried with his head to the east while a gamatch

\footnotetext{
5. Smyth 1876: 99.

36. Beveridge 1883: 21; Stone 1911: 434.

37. Stone 1911: 434.

38. Beveridge 1883: 21.

39. Littleton 1998.

40. Matthew 1899: 123.

41. Beveridge 1883: 11.

42. Curr 1965[1883]: 135.
} 
was buried with his head to the west. Of course this could only be observed when they buried in the ground. 43

Stone (based on information from informants in the Lake Boga region) writes:

Upon the death of a member of the Gourrmjanyuk tribe a shallow grave would be dug generally in a sandy spot, to a depth of about two or three feet. The bottom of the excavation would then be strewn with grass thickly, and covered with a sheet of bark; then the body was wrapped in a rug and laid on the bark, upon its back, with the head generally in the direction of the setting sun. It was then covered with grass, and finished with a sheet of bark, and then the grave was filled in. In many cases the tomahawk and grinding stones of the deceased were placed at his side, and buried with him, and I have particularly noticed in the Boga district that the stones buried with the body are invariably chipped or broken right through. ${ }^{44}$

In a clear indication of the difference between these normative accounts and individual observations he notes in his own excavation at Lake Boga the variability in position and orientation.

There are also the categories of deaths that did not fit (even at the time) into these normative rules. These are generally the deaths associated with disasters such as epidemics, ${ }^{45}$ massacre ${ }^{46}$ and homicide. ${ }^{47}$ Given that so many of the descriptions of burials are either not from direct observation but rather from oral accounts, or have been summarised over time, it is understandable that the historic accounts veer towards a notion of strong normative practice and adhere to that even in the face of evidence to the contrary.

\section{Burial and belongings}

Personal possessions are often mentioned as buried with the dead ${ }^{48}$ and this occurs in contemporary accounts as well as those of traditional practice. Stone for instance notes that the grandfather of an Aboriginal man he knew was buried with his tomahawk around 1830-1840. ${ }^{49} \mathrm{~A}$ more recent burial on the Serpentine Creek (probably dating from the first half of the 20th century) is described by Eastman:

From Jay Jay came the solution of a find revealed by the plough in running a channel for irrigation round a sandhill on this property. A heap of bones was first reveal ed, crumbling away to powder after exposure. Enquiring from Jay Jay as to this, evidently an aboriginal skeleton in sitting pose, buried a couple of feet from the surface, he said 'That poor canoe... Billy had burial in the old style. I helped to bury him. We put his stone tomahawk and a two pound station cheque alongside of him to give poor fellow good send off. ${ }^{50}$

\footnotetext{
43. Cited in Campbell 1994: 32.

44. Stone 1911: 458.

45. Beveridge 1863-4: 14.

46. Sturt 1849: 93.

47. Phillips 1893: 76.

48. Beveridge 1863-4: 20; Phillips 1893: 74.

49. Stone 1911.

50. Eastman 1953: 131.
} 


\section{The creation of a visible monument}

The final stage of the actual burial was often the creation of a visible monument. A large amount of the information on regional variability is based upon these material remains rather than the less easily accessible information on the actual burial ceremony. The accounts vary by region and indicate different temporal durations for the visible traces of a burial. Mitchell is one of the first to comment on these monuments and their form:

We continued our journey, and soon found all the usual features of the Darling the hills of soft red sand near the river, covered with the same kind of shrubs seen so much higher up. The graves had no longer any resemblance to those on the Murrumbidgee and Murray, but were precisely similar to the places of interment we had seen on the Darling, being mounds surrounded by, and covered with, dead branches and pieces of wood. On these lay, the same singular casts of the head in white plaster, which we had before seen only at Fort Bourke. It is, indeed curious to observe the different modes of burying, adopted by the natives on different rivers. For instance, on the Bogan, they bury in graves covered like our own, and surrounded with curved walks and ornamented ground. On the Lachlan, under lofty mounds of earth, seats being made around them. On the Murrumbidgee and Murray, the graves are covered with well thatched huts, containing dried grass for bedding, and enclosed by a parterre of a particular shape, like the inside of a whale boat. On the Darling, as above stated, the graves are in mounds, covered with dead branches and limbs of trees and are surrounded by a ditch, which here we found encircled by a fence of dead limbs and branches. ${ }^{51}$

Krefft similarly notes variation across space:

Between Lake Boga and the junction of the Murrumbidgee ... We passed several graves, the last near Coghill's Station, of the simple form noticed at Gunbower Creek, whilst a little further on a regular hut had been erected over the departed native; and at Hamilton's Station were two graves of this description in a very good state of preservation. The form of these sepulchres changed again soon, being instead of bark, covered with grass and reeds; a fishing net generally enclosing the whole fabric. ${ }^{52}$

Mounds are mentioned across the area but most commonly on the Lachlan, Murrumbidgee and towards the upper M urray. Hobler, in describing an old man's burial at $\mathrm{N}$ ap Nap on the Lower Murrumbidgee, writes of bark being piled on the grave ${ }^{53}$ Jamieson talks of the grave being covered over with bark and finished with earth, ${ }^{54}$ and Mackenzie similarly of the grave being covered over with bark and finished with earth. ${ }^{55}$ Moorhouse, however, writing from M oorundi on the central Murray, says:

The grave is filled up with branches and earth, and a tumulus is left so as to remind the living where their relatives and friends are laid. Upon these tumuli clothing and branches are put from time to time. ${ }^{56}$

51. Mitchell 1838II: 113.

52. Krefft 1865: 362.

53. Hobler 1992[1882]: 7 March 1847.

54. Jamieson in Bride 1969: 382.

55. Mackenzie 1870: 137.

56. Moorhouse 1844: 357. 
Most authors do not describe the size of the mound and no doubt this was variable. One account, probably from near Junee, is of a large mound around two feet high:

There a grave is dug, to a depth of say 18 inches by about 3 feet square. Sometimes the hole is made circular. A wooden shovel is used for digging purposes. The departed member of the tribe is then placed in the hole, in his squatting posture. All round to a radius of about twenty feet, the ground is loosened and the soil thrown over the grave till there is a mound about two feet above his head. The heap is gradually sloped off. Sticks and dead wood are then gathered up and placed on top to prevent the native dogs from getting at the carcase [sic] and dragging it out. When that part of the ceremony is disposed of, three or four trees in the vicinity are selected, the bark is stripped off to a length of about four feet and as wide as the trees will allow and on the bare part of the tree marks are made to correspond with the marks on the dead man's possum cloak for I might say that each man's rug is peculiarly marked in order to signify its respective ownership. ${ }^{57}$

This account is similar to Cunningham's description ${ }^{58}$ on the Lachlan, and the conjunction of a mound with carved trees does seem to be specific to the upper Lachlan and possibly upper Murrumbidgee. It corresponds to Gribble's attribution of the practice to the Wiradjuri:

With the Wiradjuri, Bulungal, that is, 'death', is the passing away of the Jir, 'ghost' or 'spirit'. After death the body is rolled tightly in a skin rug, and then placed in a grave about four feet deep. All the personal property except perhaps some choice articles, are then laid on the top and the grave filled with sticks and bark, covered over with earth and with large logs placed on it. The surrounding trees are marked, the grave is left, no one going near it and none speaking of it. ${ }^{59}$

An al ternative to the mound is a pile of logs. ${ }^{60}$ Curr writes that burial was:

generally in a sandhill, in which a grave about four feet deep had been excavated. A sheet of bark was then placed over the corpse, the sand filled in, and a pile of logs above seven feet long and two feet high was raised over all. Round about the tomb it was usual to make a path, and not unfrequently a spear, surmounted by a plume of emu feathers, stuck at the head of the mound, marked the spot where rested the remains of the departed. ${ }^{61}$

It is not clear from Curr's account where this practice was observed, although it seems most likely that this comes from his observations around Tongala and the MoiraMillewa.

Further down river - according to $\mathrm{Krefft}^{62}$ and Robinson ${ }^{63}$ probably around and below the Murray-Murrumbidgee junction - huts are mentioned as surmounting graves. There does not seem, however, to have been a clear regional division, since Eyre describes a hut in the area of Lake Boga, ${ }^{64}$ and Mitchell one on the lower Lachlan very

57. Anon 1901: 17June.

58. Cunningham 1817: 30 June.

59. Gribble in Howitt, 1904: 465.

60. For example, Mitchell 1838II: 87.

61. Curr 1965[1883]: 135.

62. Krefft 1865: 358.

63. Clark 2000: 57.

64. Eyre $1984: 152$. 
close to its junction with the Murrumbdigee, while his account of graves at Lake Benanee describes one with a hut and one with a pile of logs. ${ }^{65}$

The huts are often described as arbours of boughs. ${ }^{66}$ There were differences in construction, however. Eyre's hut near Lake Boga is described as built of reeds and covered with a net which is similar to Sturt's description of 'an oval hollow shed ... that was lined with reeds and bound together with strong network'. ${ }^{67}$ Beveridge also mentions that sometimes a net was made to cover the hut, but seems to suggest that more commonly the hut was of bark or thatch. ${ }^{68}$ In this paper I will not attempt to unscramble the variation in hut construction and its regional distribution but it is clear that there are subtle variations between accounts of huts from different areas. Some features, such as fences, seem to be very restricted in distribution. ${ }^{69}$

Not all of those who died had a visible hut. Beveridge suggests that huts are restricted to people of 'weight or consideration in the tribe'. ${ }^{70}$ Hobler's description of the old man's burial only mentions bark over the grave not a hut, ${ }^{71}$ while Mitchell's Lake Benanee account is of a child and another individual covered with a pile of logs. ${ }^{72}$ A gain the accounts are incomplete being largely restricted to the most obvious of monuments. The accounts, particularly of widow's caps in association with huts, do, however, suggest that the materiality of the grave varied with the status of the individual buried.

A part from the structures surmounting the graves, the graves were al so bounded. Fences were just one form of boundary to the grave and its surmounting structure. Cunningham's drawing and Mitchell's descriptions at Lake Benanee and on the lower Lachlan are of double or triple ridges surrounding the graves. ${ }^{73}$ Sturt describes deliberately cut walks surrounding the graves, as do Curr and Browne, while Eyre describes a trench. ${ }^{74}$ These boundaries were purposeful: the walks have the marks of women's feet upon them ${ }^{75}$ and within the fence the ground was kept clear of weeds. ${ }^{76}$

Built structures were not the only indication of a grave's presence. Curr mentions a plume of emu feathers. ${ }^{77}$ This is the only such account. M ore common, however, are references to widow's caps and kopi eggs found on the Darling and in the Darling-Murray junction area. Widow's caps are described by Mathews. ${ }^{78}$ They were made by the widow(s) of the deceased and consist of layers of gypsum plaster applied to a fibre or rush net on the woman's head. After mourning was over, the cap was taken off by the

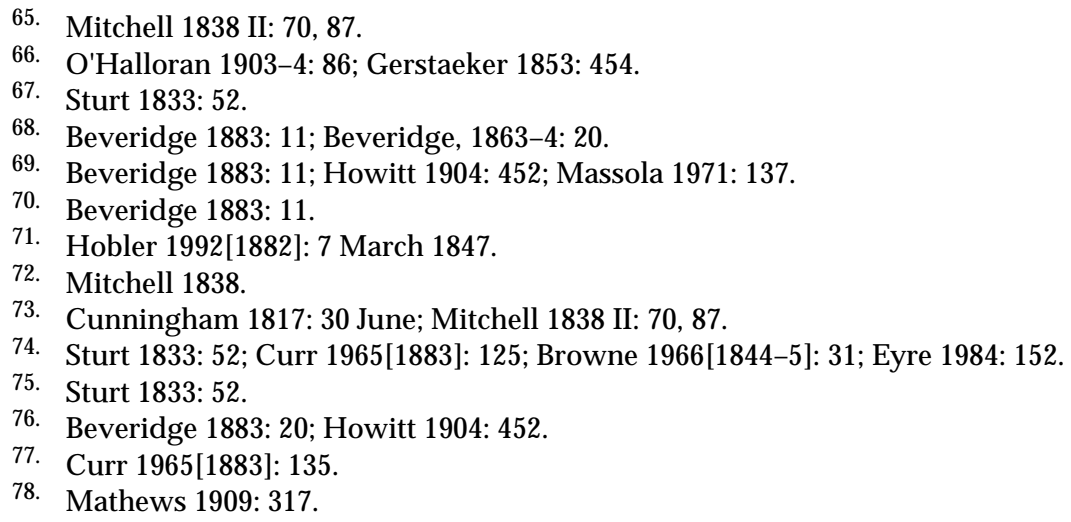


widow and placed upon the grave of her late husband. These were large solid artefacts lying on the surface beside graves, as a photograph by Reimer indicates. ${ }^{79} \mathrm{Mitchell}$ also refers to a grave surmounted with a widow's cap. ${ }^{80}$ The presence of widow's caps therefore has implications as to who was buried in a grave, indicating that the grave belonged to a married male and possibly even how many wives he had.

In contrast, kopi eggs were not restricted to the graves of males. Kopi eggs or yurda were oval shaped balls of burnt gypsum mixed with water and finesand or ashes. Accounts collected by Mathews are consistent that these objects were placed on top of the grave. ${ }^{81}$ There are, however, two, and not mutually exclusive, interpretations. The first is that the yurda were deposited by friends, the number of yurda indicating the number of friends. The second, an account from Wilcannia, is that the kopi eggs were put on the grave to induce the spirit of the dead person to remain in its place and not roam through the camp at night. ${ }^{82}$

Thus graves had a visible and material presence, al beit of varying duration. What is not clear is whether all graves were visible for some time. N or can we be certain of the extent to which such symbols could be read and interpreted by people with varying degrees of knowledge. One example of this is 'Tommy Came-First' from outside the lower Lachlan region, who, coming upon a burial hut with Mitchell, claimed it was a European grave until told otherwise by the widow hiding nearby in the bushes. ${ }^{83}$ Different people had different degrees of knowledge and hence ability to read such signs, or interpret the inscribed memory.

\section{Duration of the burial and mourning}

Prolonged mourning centred on these monuments. Initial mourning occurred within the camp, ${ }^{84}$ and accounts are given of wailing and self-mutilation. ${ }^{85}$ Merreweather observed:

By and by the visitors broke through this dead silence, and raised a long, plaintive, and not inharmonious wail, which, after a momentary pause, was responded to and prolonged by the blacks in the encampment. This was interspersed with sobs and cries on the part of the women. During the whole of the night, with short intervals, did this wild ululation fill the glades of the surrounding primeval forest; and some of the mourners made gashes on their foreheads and backs with burning sticks, sharply pointed. 86

In addition hair and beards might be cut off. Moorhouse also described people putting hot ashes on their head to 'weep in dust and ashes'. ${ }^{87}$ A part from ashes, white pipe clay is also mentioned as a marker of mourning. ${ }^{88}$ As well as making widow's

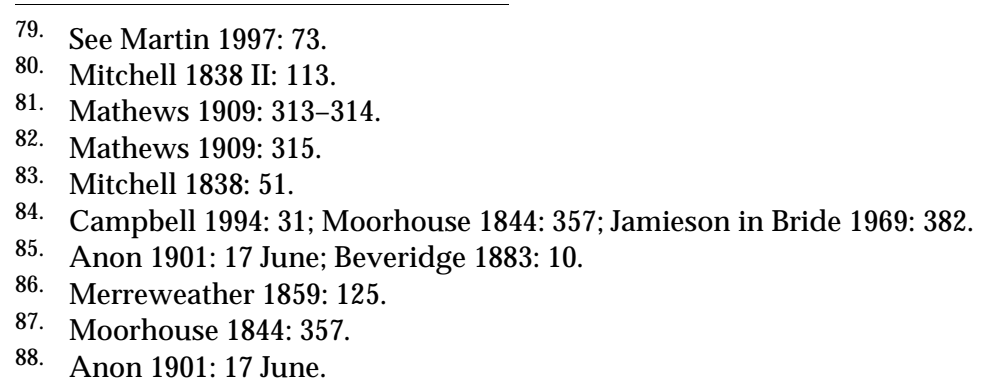


caps in the Darling-Murray area, the widows had specific practices such as firing a bush and dragging it around the camp ${ }^{89}$ before leaving and isolating herself. ${ }^{90}$ The duration of mourning varies in different accounts from three to 12 months. ${ }^{91}$

Accounts also vary in relation to maintenance of the hut and responsibility for its upkeep. Bulmer states that:

the woman went to the tomb over which she had erected a shelter, after lying on the grave for some time she would take off the plaster cap and deposit it on the grave, and go home to begin her work of collecting gypsum de novo. This she would keep up for a long time, perhaps 3 months. ${ }^{92}$

Mitchell, however, states that a male slept in the hut until 'no flesh remains on the bones' and then he 'yan' (iegoes) away. Hewas, however, told this by a widow lurking near the grave in the bushes suggesting that she had some maintenance role at the hut. ${ }^{93}$ In contrast, at Benanee, he was told that the hut surmounting one grave was burnt and abandoned once the murder had been avenged. ${ }^{94}$ Beveridge, on the other hand, suggests the grave is maintained and kept clear for about two years. Actual use of the hut is only mentioned in relation to a Baangaal:

who ever has the temerity to seek to [sic] vacant office of the defunct must go at sundown, the first night of the new moon, and place himself in the mausoleum and there remain until sunrise the following morning. This proceeding has to be continued every night until the moon has waxed and waned, and if he successfully completes the loathsome ordeal, he is deemed to have graduated satisfactorily and is subsequently inducted. ${ }^{95}$

A more generic form of acknowledgement is noted by Gerstaeker: 'It is a fashion with these tribes, as a kind of tribute to the dead, to throw, when they pass their graves, little branches or bushes upon them. ${ }^{96}$ Relics were also used and presumably memories were associated with them. ${ }^{97}$

In contrast to the accounts of desecration of graves by Europeans there are also instances where Europeans too covered graves ${ }^{98}$ sometimes in a series of activities that may reflect A boriginal practices:

My men dug a grave, and having secured the top well with stones, to prevent the wild dogs from disinterring it, crowned its summit with the murdered man's spears and other instruments of war, which remained there till some sacrilegious white hand removed them. ${ }^{99}$

89. Anon 1901: 17June.

90. Campbell 1994: 30; Jamieson in Bride 1969: 382.

91. Campbell 1994: 30; Anon 1901: 17June.

92. Campbell 1994: 30.

93. Mitchell 1838II: 70.

94. Mitchell 1838II: 87.

95. Beveridge 1863-4: 51.

96. Gerstaeker 1853: 454.

97. Jamieson in Bride 1969: 383; Anon 1901: 17June; Crombie 1927: 53.

98. Sturt 1833: 37; Hobler 1992[1882]: 7 March 1847.

99. Clow in Bride 1969: 359. 


\section{Burial prompts further action}

Apart from maintenance of the burial place for a period of time, burials prompted action in the form of avoidance of names and of the place of death. The former was widespread, ${ }^{100}$ though avoidance of place was more variable. A voidance of graves was general; so once Tommy Came-First knows the hut belongs to a grave, he avoids it. ${ }^{101}$ Similarly Hawdon notes the al oofness of A boriginal people near the grave, ${ }^{102}$ al though both Sturt ${ }^{103}$ and $\mathrm{O}^{\prime} \mathrm{Halloran}{ }^{104}$ describe walking with Aboriginal people near the mound covering those buried from the massacre. Nevertheless, camping and burials were mutually exclusive in historic accounts. Similarly if the burial was close to a camp, the camp was generally moved for at least a period:

As a rule the blacks do not tarry in a camp one moment longer than they can possibly help after a death has taken place. The gins never attend the burial but make all preparations for departure so that when the men return from the funeral all is about ready for a general departure. ... it is then twelve months before she can come anywhere near the camp again. And if she - or any relative of the deceased - does come along after that period, it is necessary to again drag a lit bush round. 105

Beveridge writes that this was sustained even during the smallpox epidemic so that burials induced two sets of activities: generalised avoidance by those unconnected with the specific burial, and deliberate and active abandonment of areas for some time by those present at the death or connected to the dead. ${ }^{106}$ There was, therefore, no generic response it depended on the relationship between the deceased and the later visitor.

\section{Burials attract burials}

Burials were frequently not solo, and there is evidence of accumulation over time. Thus Hobler's account of a burial in 1847 is an instance of grave reuse. ${ }^{107}$ Going through the accounts there is also frequent mention of around three graves. ${ }^{108}$ There are two accounts of more than this number of visible graves: one is Hawdon's description at LakeBonney. ${ }^{109} \mathrm{His} 30$ graves are unlikely to be all huts, but his description is matched by a drawing by Blandowski at Lake Bonney of a large group of burial huts. Robinson writes of defined cemeteries, counting 22 graves at one (near Moira) with single burials only lower downriver, but there is no parallel account even by Curr of this. ${ }^{110}$ These are the only two indications found so far, apart from the single mass burial at the Rufus,

100. Curr 1965[1883]: 127; H owitt 1904: 466, Jamieson in Bride 1969: 382; Beveridge 1863-4: 20; Merreweather 1859: 125.

101. Mitchell 1838 II: 70.

102. Hawdon 1952: 52.

103. Sturt 1849: 93.

104. O'Halloran 1903-4: 86.

105. Anon 1901: 17June.

106. Beveridge 1863-4: 17.

107. Hobler 1992[1882]: 7 March 1847.

108. Gerstaeker 1853; Hawdon 1952: 32; Mitchell at both the Lachlan (Mitchell 1838II: 51) and Lake Benanee (II: 87).

109. Hawdon 1952: 52.

110. Clark 2000: 57. 
which approach in expected size a visible and formal cemetery. Much more commonly the visible clusters of graves are small in number. This is not to say that there were not other graves in these places: there were potentially other contemporary unmarked graves (ie possibly those of women) and there were potentially other graves which had decayed and left no visible presence. Mitchell describes this process at Lake Bennanee, ${ }^{111}$ but, as Beveridge points out, the external visibility of graves was of limited duration: 'After that time the tomb is allowed to fall into decay, until tin the course of a few years the very site of it is forgotten. These are temporary monuments. ${ }^{112}$ Their duration was extended by their ability to attract other activities.

\section{Descriptions of erosion, collapse, forgetting}

Temporary monuments do not remain in a single state and, even in the 1800s, there is evidence of cycles of collapse, loss of memory, erosion and destruction through human activity. It is not just graves with still standing monuments that were visible: the Kerridges note that when putting in stockyards at Lake Victoria they 'dug through lots of blackfellows bones'. ${ }^{113}$ Mitchell and Sturt both described eroded graves:

A very large ash hill, raised no doubt by repeated use in such simple, culinary operations, and probably during the course of a great many years, was close to our camp. ... On its ample surface were just visible the vestiges of a very ancient grave, once encompassed by exactly the same kind of ridges that I had observed around the inhabited tomb, near the junction of the Lachlan and Murrumbidgee. ${ }^{114}$

And

We stopped for the night upon the left bank; and close to a burial-ground that differed from any I had ever seen. It must have been used many years, from the number of bones that were found in the bank, but there were no other indications of such a place either by mounds or by marks on the trees. The fact, therefore, is a singular one. I have thought that some battle might have been fought near the place, but I can hardly think one of their battles could have been so destructive. ${ }^{115}$

Two accounts from The Pastoral Times point to the destruction of burial sites:

Aug 20, 1864. While road making at North Deniliquin the other day, the skull and bones of a blackfellow were dug up, which an aboriginal standing by declared to be the remains of Old Deniliquin. 116

March 13, 1880. We have taken from him his hunting forests and his camping grounds. The favourite tree under which he rested so long, until he came to recognise it as his home, has not been spared by the ruthless hands of our woodsman. The very mound in which he had concealed his dead has been broken up by the plough of the Husbandman. ${ }^{117}$

\footnotetext{
111. Mitchell 1838II: 87.

112. Beveridge 1863-4: 20.

113. Cited in Hope 1998: 101.

114. Mitchell 1838 II: 149.

115. Sturt 1833: 137.

116. Mulham 1994: 2.

117. Mulham 1994: 6.
} 
These accounts of visible destruction and erosion are mirrored by the photographs taken by Reiner at Lake Victoria: one of a still-standing burial hut over a grave al ongside a collapsed hut and at least 32 widow's caps. ${ }^{118}$ The accompanying newspaper article suggests that the grave may have been constructed 30 years earlier. The other Reiner photograph is of human remains on the shore of LakeVictoria. Clearly, the monuments are temporary and have a limited duration, but this temporary visibility provokes a response.

\section{Discussion: burials and duration}

In this survey of historic accounts of burial, the material presence is very apparent in contrast to the relatively sparse accounts of the actual activity of burial. This imbalance is a direct reflection of the different temporal scales associated with burials. Because, particularly early on, there were relatively few Europeans and burials were often uncommon and private events, the actual accounts of them are few and the more general accounts of monuments tend heavily towards the normative, which does not correspond in every instance to either the author's own experience or to the single accounts that exist. In other words, written accounts of burials - particularly those by ethnographers - tend to give idealised and partial accounts. A similar phenomenon is noted by Woodburn in his work on hunter-gatherer burials in Africa. As he points out: 'human death is relatively invisible in these societies ... This means that inevitably anthropologists will, at best, have only been able to observe a small number of instances and most rely heavily on informants' statements.' 119

Apart from the variations over space and due to the age and status of the deceased, the accounts indicate how a burial in itself was a social act and also an act with further ramifications. Whereas the burial, for most people, was over within 24 hours and whereas the mourning and maintenance of the place continued for 12 months or longer, avoidance of the place persists until the monuments decay. The decay was itself a process taking one to four generations (judging by Reiner and Massola's photographs), and then, of course, some burials were later disturbed and bought to the surface by erosion and earth-moving activities. During those stages people are variably involved. While there are collective accounts of how burials should be done, the actual memory and knowledge of specific burials was held by relatively few: primarily those present at the death and, in particular, those related to the deceased. In this set of accounts memories of burials lie in the 'immediate short-term sense of life histories and localized habits'. ${ }^{120}$ The visibility of burial places, however, creates a longer and more widespread set of inscribed memories: identifying places as part of a mortuary landscape, circumscribing future action, prompting other actions. From this there is the potential for accumulation of mortuary remains over long periods of time so the historic accounts of burial are virtual palimpsests incorporating actions and objects operating and persisting on widely differing temporal scales.

Europeans as well as A boriginal people reacted (and continue to react) to these vestigal signs. The very materiality of burials demands a response from later inhabit-

118. Martin 1997: 72.

119. Woodburn 1982: 202.

120. Blake 2003: 218. 
ants, but that response is not necessarily dependent upon specific memories or a single collective memory. Some places were still accumulating burials at the time of European invasion, while at others the process of erosion and temporary exposure was underway. It is difficult to go from these descriptions of the range of activities associated with death and burial to predictions concerning the archaeological landscape of burials in this part of the Murray. The focus of the archaeological record is on the burial. Attention can be paid to the actual placement of the body but this leaves out all the ancillary activities documented above. The age, sex, number of burials in a location, orientation, body position and whether a burial is primary or secondary all give the impression of fullness of information, but in reality the burial remains are a restricted vision of one quite specific part of an entire process. A rchaeological accounts, like those of the generalising historians, focus on the normative (or central tendency), but individual historical accounts indicate the underlying messiness and variability associated with burials. These historical accounts suggest that the visible archaeological patterning may emerge from an interaction between time, specific memories and ideas about what elements of a person and their death were important, rather than strict cultural rules. It also means, however, that we should be aware in relation to historical accounts, that there is a real difference between the accounts of actual events at a moment in time and those accounts when time is compressed into a single narrative. Neither of these accounts corresponds to the archaeological record.

\section{Acknowledgments}

Part of this research was conducted under an Institute of A boriginal and Torres Strait Islander Studies grant. My thanks also go to members of the Wamba Wamba Local A boriginal Land Council with whom I worked. Melinda Allen, Harry Allen, Christine Dureau and Simon Holdaway have all read various drafts of this manuscript and I am grateful for their constructive comments as well as those of the reviewers. Thanks also to Seline MacN amee for the map.

\section{References}

\section{Primary sources}

Cunningham, A 1817, D iary of a journey with Oxley in 1817, Mitchell Library, Sydney.

Mein, P 1897, 'Letter to H.C. Russell', 25 October, Mitchell Library, Sydney.

\section{Secondary sources}

A non 1901, 'The autobiography of an interesting old native', Junee Southern Cross, 11,15 May and 17June.

Beveridge, P 1863-4, 'A few notes on the dialects, habits, customs and mythology of the Lower Murray A borigines', Transactions of the R oyal Society of V ictoria 6: 14-24.

- 1883, 'Of the A borigines inhabiting the great lacustrine and riverine depression of the lower Murray, lower M urrumbidgee, lower Lachlan, and lower Darling', Journal and Proceedings of the Royal Society of $N$ ew South W ales 17: 1-56.

Blake, S 2003, 'The familiar honeycomb: Byzantine Era reuse of Sicily's prehistoric rockcut tombs', in The archaeology of memories, R van Dyke and SAlcock (eds), Blackwell, Oxford: 203-220. 
Bradley, R 2000, A rchaeology of natural places, Rutledge, N ew York.

Bride, T (ed) 1969, Letters from V ictorian pioneers, Heinemann, Melbourne.

Browne, J 1966 [1844-5], 'Dr John Harris Browne's journal of the Sturt Expedition, 1844-5', South A ustraliana 5: 23-54.

Bulmer, J 1888, 'Some accounts of the A borigines of the Lower Murray, Wimmera, Gippsland and Maneroo', Proceedings of the Geographical Society of V ictoria 1: 15-43.

Campbell, A 1994, V ictorian A borigines: John Bulmer's recollections 1855-1908, Occasional Papers A nthropology and History, Museum of Victoria N o 1, M useum of Victoria, Melbourne.

Clark, ID (ed) 2000, The journals of G eorge A u gustus R obinson, chief protector, Port Phillip A boriginal Protectorate, vol 4: January 1844 - 240 ctober 1845, Heritage Matters, Melbourne.

Crombie, A 1927, A fter sixty years, or, recollections of an A ustralian bushman, Watson Ferguson and Co, Brisbane.

Curr, EM 1965 [1883], Recollections of squatting in V ictoria, Melbourne University Press, Melbourne.

Dowling, P 1997, 'A great deal of sickness', PhD thesis, Australian National University, Canberra.

Eastman, H 1953, M emoirs of a stockman, Halstead Press, Deniliquin.

Eyre, E.J 1984, A utobiographical narrative of residence and exploration in A ustralia 18321839, Caliban Books, London.

Gerstaeker, F 1853, N arrative of a journey around the world, Harper and Bros, New York.

Hawdon, J 1952, The journal of a journey from $\mathrm{N}$ ew South Wales to A delaide in 1838, Georgian House Pty Ltd, Melbourne.

Hobler, G 1992 [1882], The diaries of 'P ioneer' G eorge H obler O ct 6, 1800 - D ec 13, 1882, C \& H Reproductions, Sydney.

Hope, J 1998, 'The cultural heritage of Lake Victoria', History background paper no. 7, Report to the Murray Darling Basin Commission, Canberra.

Howitt, AW 1904, The native tribes of south-east A ustralia, MacMillan, London.

Kirby, J 1896, Old times in the bush, James Curtis, Ballarat.

Krefft, G 1865, 'On the manners and customs of the A borigines of the Lower Murray and Darling', Transactions of the Philosophical Society of N ew South W ales 1862-5: 35774.

Littleton, J 1998, 'East and west: burial practices along the Murray River', A rchaeology in 0 ceania 34: 1-14.

— 2002, 'M ortuary behaviour on the Hay Plain: do cemeteries exist?', A rchaeol ogy in 0 ceania 37: 105-122.

Mackenzie, D 1870, Ten years in A ustralia being the results of his experience as a settler during that period, 3rd edn, William S Orr and Co, London.

Martin, S 1997, 'Lake Victoria EIS', Anthropological report background paper no. 5, Report to the Murray Darling Basin Commission, Canberra.

Massola, A 1971, The A borigines of south-eastern A ustralia as they were, William Heinemann, Melbourne. 
Mathews, RH 1909, 'Some burial customs of the Australian A borigines', P roceedings of the A merican Philosophical Society 48: 313-318.

Matthew, J 1899, Eaglehawk and Crow, Melville, Muller and Slade, Melbourne.

Meehan, B 1971, 'Theform, distribution and antiquity of Australian A boriginal mortuary practices', MA thesis, University of Sydney, Sydney.

Merreweather, J 1859, D iary of a working clergyman in A ustralia and Tasmania, Hatchard, London.

Mitchell, TL 1838, Three expeditions into the interior of eastern A ustralia: with descriptions of the recently explored region of A ustralia Felix, and of the present colony of $\mathrm{N}$ ew South W ales, vol II, T and W Boone, London.

Moorhouse, M 1844, B ritish Parliamentary Papers: Colonies A ustralia 8: 355-360.

Moulden, B 1872, Journal of a canoe trip 200 miles down the River M urray, Christmas, 1872, Webb, Vardon \& Pritchard, Adelaide.

Mulham, WE 1994, The best crossing place, Reliance Stationery and Printery, Deniliquin. Musgrave, Sara 1930, The way back, Cumberland Argus, Parramatta.

O'H alloran, T 1903-4, From A delaide al ong the River M urray to the Rufus and Lake Victoria, Proceedings of the R oyal Geographical Society of Australasia, South Australian Branch 7: 70-91.

Olivier, L 1999, 'The H ochdorf “princely" grave and the question of the nature of archaeological funerary assemblages', in Time and archaeology, T M urray (ed), Routledge, London: 109-135.

Pardoe, C 1988, 'The cemetery as symbol: the distribution of prehistoric A boriginal burial grounds in southeastern A ustralia', A rchaeology in 0 ceania 16: 173-178.

— 1995, 'Riverine, biological and cultural evolution in southeastern A ustralia', Antiquity 69(265): 696-714.

Phillips, J 1893, Reminiscences of A ustralian early life, AP Marsden, London.

Russell, L 1990, 'Funerals and graves: a study of mortuary practices in southern east Australia', BA(Hons) thesis, La Trobe University, Melbourne.

Smyth, R Brough 1876, The A borigines of V ictoria and other parts of A ustralia and Tasmania, John Curry, O'Neill, Mel bourne.

Stone, AC 1911, 'The A borigines of Lake Boga', Proceedings of the R oyal Society of V ictoria 23: 434-468.

Sturt, C 1833, T wo expeditions into the interior of southern A ustralia, during the years 1828, 1829,1830 , and 1831: with observations on the soil, climate, and general resources of the colony of $\mathrm{N}$ ew South Wales, Smith, Elder and Co, London.

- 1849, $\mathrm{N}$ arrative of an expedition into central A ustralia, performed under the authority of Her M ajesty's government, during the years 1844,5 , and 6: together with a notice of the province of South A ustralia in 1847, T and W Boone, London.

Witter, D, R Fullagar and C Pardoe 1993, 'The Terramungamine incident: a double burial with grave goods near Dubbo, New South Wales', Records of the A ustralian M useum Supplement 17: 77-89.

Woodburn, J 1982, 'Social dimensions of death in four A frican hunting and gathering societies', in D eath and the regeneration of life, M Bloch (ed), Cambridge University Press, Cambridge: 187-211. 